\title{
PEMANFAATAN YOUTUBE DALAM UPAYA MENINGKATKAN KETERAMPILAN MASYARAKAT RW.06 CIBEBER MENGENAI PENGELOLAAN SAMPAH
}

\author{
Jihan Shavira Nurislam \\ IKIP Siliwangi, Cimahi -Jawa Barat - Indonesia \\ jihanshafira88@gmail.com
}

Received: Januari, 2020; Accepted: Mei, 2020

\begin{abstract}
This research is motivated by the fact that there are garbage problems in the Cibib community that makes people uneasy. The aim is to increase community creativity in waste management. Then the theoretical basis used in this theory is YouTube utilization theory, waste management theory and community development theory. The research method used is qualitative by describing what has been studied and direct observation. The results of this study indicate that the use of social media youtube is very useful to provide understanding to the community in improving skills in waste management. The conclusion from this study shows that the use of social media is very necessary so that people are aware and understand how to manage waste that is of no value into valuable goods.
\end{abstract}

Kata Kunci: YouTube utilization, waste management.

\begin{abstract}
Abstrak
Penelitian ini dilatar belakangi oleh fakta adanya permasalahan sampah yang ada di lingkungan masyarakat cibeber yang membuat resah. Tujuannya adalah untuk meningkatkan kreativitas masyarakat dalam pengelolaan sampah. Kemudian landasan teori yang digunakan dalam teori ini adalah teori pemanfaatan youtube, teori pengelolaan sampah dan teori pengembangan masyarakat. Metode penelitian yang digunakan adalah kualitatif dengan mendeskripsikan apa yang sudah diteliti dan melakukan observasi secara langsung. Hasil dari penelitian ini menunjukan bahwa media sosial youtube sangat bermanfaat untuk memberikan pemah aman terhadap masyarakat dalam meningkatkan keterampilan dalam pengelolaan sampah. Kesimpulan dari penelitian ini menunjukan bahwa pemanfaatan media sosial sangat diperlukan agar masyarakat sadar dan paham bagaimana cara mengelola sampah yang asalnya tidak bernilai menjadi barang yang bernilai.
\end{abstract}

Keywords: pemanfaatan youtube, pengelolaan sampah.

How to Cite: Nurislam, J.S. (2020). Pemanfaatan Youtube Dalam Upaya Meningkatkan Keterampilan Masyarakat RW 06 Cibeber Mengenai Pengelolaan Sampah. Comm-Edu (Community Education Journal), 3 (2), 102-108.

\section{PENDAHULUAN}

Permasalahan sampah di Negara Indonesia sudah menjadi permasalahan yang besar bagi masyarakat di Indonesia karena pertumbuhan penduduk yang semakin meningkat, pemerintah memang sudah harus mempercepat untuk mengubah sistem pengelolaan sampah.. Persoalan sampah plastik ini bukan hanya di negara berkembang saja, tetapi juga menjadi isu yang hangat di negara-negara besar di dunia. Kebanyakan sampah-sampah ini adalah sampah plastik. Sebuah lembaga peneliti di Negara Indonesia pada tahun 2018 menyebutkan bahwa kurang dari 150 juta ton sampah plastik telah mencemari lautan. Penelitian yang dilakukan oleh R.Jambeck pada tahun 2015 ini juga menyebutkan hal yang sama. Negara Indonesia menempati peringkat kedua setelah Tiongkok dalam permasalahan sampah. Menurut Direktur 
Pengelolaan Sampah Lingkungan Hidup dan Kehutanan (KLHK) salah satu masalah dasar dalam pengelolaan sampah di Negara Indonesia adalah rendahnya kapasitas pemerintah dalam mengelola sampah juga tidak adanya kesadaran bagi masyarakatnya akan kepedulian sampah.

Jawa Barat secara nasional menjadi provinsi penghasil sampah plastik terbanyak. Produksi sampah warga Jabar mencapai 28.000 ton/ hari. Dalam tiga tahun rata-rata kenaikan 1000 ton, tercatat Kabupaten Bogor merupakan daerah tertinggi penghasil sampah plastik . Ketua Wahana Lingkungan Hidup Indonesia (Walhi) Jawa Barat, Meiki.W.Paendo (Kota Cimahi Hasilkan 300 Ton Sampah Perhari, 2019) mengemukakan, berdasar data dari Kementerian Perindustrian, konsumsi plastik meningkat sekitar 5\% dalam lima tahun terakhir dengan penghasil plastik tertinggi berasal dari industri makanan dan minuman, kantong plastik, produk kebersihan. Besarnya sampah plastic di Jawa Barat tidak jauh dari jumlah penduduknya, Jabar merupakan provinsi paling banyak penduduknya.

Menurut Kepala Dinas Lingkungan Hidup (DLH) pertambahan jumlah sampah yang tidak diimbangi dengan pengelolaan sampah berbasis masyarakat yang ramah lingkungan dapat menyebabkan pencemaran lingkungan (Kustiah, 2005). Sebagai contoh di Kota Cimahi Produksi sampah domestik di Kota Cimahi dianggap sudah terlalu berlebihan. Faktanya, dalam sehari Kota Cimahi menghasilkan sampai 300 ton sampah berbagai jenis. Persentase kantong plastik dari sampah yang dihasilkan mencapai 30 persen. Dan jumlahnya bisa terus bertambah bila tak dikendalikan. Mochamad Ronny, kantong plastik sekali pakai yang banyak digunakan baik di pasar modern maupun pasar tradisional sangat sulit diurai dan sulit didaur ulang. "Sekitar 90 ton sampah dari Cimahi itu berupa plastik sekali pakai. Artinya masyarakat masih ketergantungan, padahal sulit diurai. Kita upayakan jangan banyak sampah anorganik yang dibuang ke TPA," ungkap Ronny saat ditemui di Pemkot Cimahi, Selasa, 26 Februari 2019 (Jumlah Sampah kota cimahi, 2019).

Sampah yang tidak diolah dengan baik dapat menimbulkan pencemaran lingkungan, lingkungan yang tercemar akan mengganggu kesehatan manusia yang akan menimbulkan penyakit. Oleh karena itu, pengelolaan sampah mesti dilakukan dengan bijak menggunakan cara-cara yang sederhana. Ternyata sampah yang biasanya kita buang dan kita anggap menjadi barang tidak berguna ini dapat diolah dengan baik menggunakan teknik-teknik yang sederhana. Disamping itu, perlunya kesadaran akan pemahaman pentingnya pengelolaan sampah harus diberikan terhadap masyarakat dalam upaya meningkatkan pengelolaan sampah agar masyarakat dapat menjaga kebersihan dan perduli akan lingkungannya juga masyarakat dapat mengelola sampahnya sendiri minimal sampah-sampah rumah tangga yang ada di rumahnya sendiri.

\section{KAJIAN TEORI}

\section{A. Pengertian Youtube}

YouTube merupakan media social berupa video sharing (berbagi Video) dimana pengguna dapat mengakses informasi secara gratis. Berdirinya Youtube pada februari 2005 oleh tiga orang karyawan mantan Paypal yaitu Chad Hurley, Steve Chen dan Jawed Karim. Video di youtube pada umumnya adalah buatan para penggunanya sendiri (Widika, 2013).

Youtube menjadi salah satu media sosial paling menonjol di dunia karena menguasai $43 \%$ pasar. Diperkirakan hasil dari penggunaan youtube selama dua puluh jam durasi video yang diupload oleh pengguna setiap menitnya adalah enam milyar yang melihat perhari. Youtube 
104 Nurislam, Pemanfaatan Youtube Dalam Upaya Meningkatkan Keterampilan Masyarakat RW 06 Cibeber Mengenai Pengelolaan Sampah

memiliki lebih dari satu milyar pengguna, karena setiap hari orang menonton ratusan juta video yang ada di youtube dan menghasilkan milyaran kali penayangan video. Youtube telah berhasil menjangkau manusia dari muda hingga tua karena kemudahan dan fitur yang sangat mendukung bagi kebutuhan kehidupan manusia di dunia.

\section{B. Manfaat Youtube}

Manfaat penggunaan youtube:

1. Youtube memberikan layanan yang mudah diakses oleh siapapun dan gratis. Artinya pengguna dapat mengakses apapun untuk memperoleh informasi.

2. Youtube memiliki fitur Men-download untuk beberapa video yang akan memungkinkan pengguna bisa menyimpan beberapa kali video yang diunduh.

3. Mengakses beberapa informasi untuk melakukan beberapa hal tertentu. Misalnya, mengakses cara pengelolaan sampah dengan baik dengan berbagai keterampilan untuk mengasah berbagai skill dan lain sebagainya.

4. Youtube memiliki fitur video streaming yang membuat penggunaan youtube lebih bisa mengakses secara luas baik live ataupun tidak.

5. Youtube dapat memperluas jangkauan pemasaran produk yang kita miliki.

6. Mengakses Video Informatif. Youtube dapat menjadi sebuah referensi penyedia informasi karena hanya dengan mengakses youtube kita dapat melihat informasi apapun yang diinginkan.

7. Youtube memiliki fitur suka dan komentar khalayak sehingga memudahkan penggima dalam mengetahui respon konsumen terhadap video yang diunggah (Fatty Faiqah, 2016).

8. Youtube sebagai hiburan bagi penggunanya karena youtube menyediakan berbagai video menarik yang dapat sangat mudah untuk diakses sesuai dengan kebutuhan pengguna

\section{Pengertian Sampah}

Menurut (Mursidi, Fitriah, \& Aldiawan, 1019) sampah merupakan "sesuatu yang tidak digunakan, yang berasal dari kegiatan manusia tapi bukan secara biologis". Menurut definisi World Health Organization (WHO) sampah adalah sesuatu yang tidak digunakan, tidak dipakai, tidak disenangi atau sesuatu yang dibuang yang berasal dari kegiatan manusia dan tidak terjai dengan sendirinya (Chandra \& Budiman, Pengantar Kesehatan Lingkungan, 2006) Berdasarkan pendapat diatas maka sampah adalah semua jenis benda yang sudah tidak digunakan dari aktivitas manusia yang dapat menimbulkan pencemaran lingkungan (Rizal, 2011)

\section{Pengelolaan Sampah}

Pengelolaan sampah adalah kegiatan mendaur ulang sampah yang sudah tidak ada nilainya menjadi sebuah barang yang bernilai. Dalam pengelolaan sampah meliputi pengumpulan, pengangkutan dan pembuangan akhir. Pengumpulan sampah diartikan sebagai pengumpulan dari tempat sebelumnya ke tempat pembuangan sementara untuk dilakukan proses selanjutnya. Tahapan pengangkutan dilakukan menggunakan transportasi dari tempat pembuangan sebelumnya ke tempat pembuangan akhir. Di tempat pembuangan akhir sampah mengalami proses biologis, kimia dan secara fisik sampai tuntas penyelesaian hingga proses akhir. Pengelolaan sampah harus dilakukan dengan baik karena jika tidak dikelola dengan sebaik-baiknya akan menimbulan beberapa permasalahan lingkungan juga mengganggu kesehatan masyarakat (Pengertian Pengelolaan Sampah). 


\section{E. Keterampilan Pengelolaan Sampah}

Keterampilan merupakan pemberian motivasi melalui potensi yang dimilikinya kepada anggota masyarakat lain yang membutuhkannya. Dengan maksud agar orang tersebut dapat melakukan kegiatan yang dapat menigkatkan kesejahteraan sosialnya. Keterampilan mengelola sampah merupakan suatu bentuk kreatifitas terhadap pengelolaan sampah yang dibuat menjadi barang yang bisa digunakan kembali sehingga bernilai. Barang dapat berupa produk ataupun hiasan dari barang yang sudah tidak terpakai.

\section{F. Manfaat keterampilan sampah dalam masyarakat}

Masyarakat dapat mengelola sampah menjadi produk yang bernilai jika dapat diolah dan dibuat keterampilan secara baik. Sampah dapat menghasilkan produk baru jika dikemas dengan baik dengan menggunakan teknik-teknik tertentu yang bisa digunakan yang akan menghasilkan barang yang memiliki nilai jual jika dimanfaatkan dengan baik. Salah satu pemanfaatan youtube dalam upaya meningkatkan keterampilan pengelolaan sampah adalah dengan memberikan pemahaman-pemahaman kepada masyarakat bahwa sampah dapat menjadi barang yang bernilai dan memiliki harga jual yang tinggi jika dikemas secara baik.

\section{G. Teori Pengembangan Masyarakat}

"Pengembangan masyarakat (community development) dalam istilah bahasa Arab disebut dengan pengembangan masyrakat, merupakan wawasan dasar bersistem tentang asumsi perubahan sosial terancang yang tepat dalam kurun waktu tertentu (Zubaedi, 2013).

Pengembangan masyarakat (community development) terdiri dari dua konsep, yaitu "pengembangan" dan "masyarakat". Pengembangan dan pembangunan merupakan usaha bersama untuk meningkatkan kualitas hidup yang meliputi bidang ekonomi, pembangunan, pendidikan, sosial budaya dan kesehatan. Masyarakat diartikan menjadi dua konsep:

1. Masyarakat sebagai sebuah tempat bersama artinya masyarakat satu wilayah geografi yang sama. Sebagai contoh, sebuah rukun tetangga, perumahan didaerah perkotaan atau sebuah kampung di wilayah pedesaan.

2. Masyarakat sebagai kepentingan bersama yang berdasarkan kebudayaan dan identitas. Contohnya kepentingan bersama berdasarkan kebutuhan tertentu seperti perubahan sosial.

\section{METODE}

Pendekatan yang digunakan oleh peneliti adalah pendekatan penelitian kualitatif. Menurut (Sugiyono, 2011)landasan metode penelitian ini filsafat postpotivisme, peneliti sebagai instrumen kunci dan digunakan pada objek yang alamiah. Teknik pengumpulan data dilakukan secara triangulasi (gabungan) analisis data bersifat kualitatif dan hasil penelitian kualitatif lebih menekankan makna yang terkandung didalamnya dibandingkan secara general. Metode penelitian yang digunakan yaitu dengan metode deskriptif. Alasan peneliti menggunakan pendekatan kualitatif deskriptif, karena pembahasan yang sedang di bahas oleh peneliti tidak berhubungan dengan angka-angka melainkan pendeskripsian, penguraian dan penggambaran suatu masalah yang sedang terjadi. Adapun teknik pengumpulan data, penulis menggunakan metode observasi, wawancara, dan dokumentasi. Penulis juga menggunakan pedoman wawancara (interview guide) untuk memperoleh tujuan penelitian. Penelitian ini dilaksanakan di kediaman bapak Rw setempat juga ibu-ibu PKK. Lokasi penelitian ini di Rw.06 Cibeber Cimahi. Subjek penelitian ini adalah ibu-ibu PKK dan masyarakat Rw.06 Cibeber Cimahi. Teknik analisis data meliputi: (1) Reduksi data (2) Display data (3) Kesimpulan. 
106 Nurislam, Pemanfaatan Youtube Dalam Upaya Meningkatkan Keterampilan Masyarakat RW 06 Cibeber Mengenai Pengelolaan Sampah

\section{HASIL DAN PEMBAHASAN}

\section{Hasil}

Berdasarkan penelitian dilapangan, berikut ini peneliti akan memaparkan hasil penemuan dilapangan yang sesuai dengan pertanyaan penelitian yaitu 1. Bagaimana pemanfaatan youtube dalam meningkatkan keterampilan pengelolaan sampah di Rw.06 Cibeber? 2. Bagaimana cara meningkatkan pemahaman kepada masyarakat dalam pemanfaatan sampah melalui youtube? 3. Bagaimana hambatan-hambatan yang di hadapi dalam meningkatkan keterampilan pengelolaan sampah?

Pertama mengenai bagaimana pemanfaatan youtube dalam meningkatkan keterampilan pengelolaan sampah di Rw.06 Cibeber. Berdasarkan hasil wawancara dan pengamatan bahwa warga sekitar sangat antusias ketika diberikan pemahaman mengenai tata cara penggunaan youtube, khususnya untuk menonton dan mengaplikasikan konten keterampilan pengelolaan sampah yang dikemas secara baik dan sangat mudah untuk diaplikasikan.

Kedua mengenai bagaimana cara meningkatkan pemahaman masyarakat dalam pemanfaatan sampah melalui youtube. Berdasarkan hasil lapangan peneliti melaksanakan penyuluhan yang mengikutsertakan masyarakat Rw.06 Cibeber akan pentingnya mengelola sampah menjadi barang yang bermanfaat. Peneliti menyampaikan informasi kepada masyarakat mengenai penggunaan youtube sebagai alat informasi mengenai bagaimana cara membuat keterampilan dari bahan yang sudah tidak terpakai. Dalam kegiatan penyuluhan tersebut, peneliti sekaligus mengajak masyarakat untuk mempraktikkan langsung cara mengolah sampah menjadi barang yang bisa bermanfaat kembali.

Ketiga mengenai bagaimana hambatan-hambatan yang di hadapi dalam meningkatkan keterampilan pengelolaan sampah. Berdasarkan hasil pengamatan dilapangan peneliti mendapatkan hasil bahwa setelah diadakannya penyuluhan dan pelatihan dalam pengelolaan sampah perlu diadakannya pengecekan secara berkelanjutan agar masyarakat dapat terus mengaplikasikan keahlian softskilsnya dengan baik.

\section{PEMBAHASAN}

Pembahasan yang pertama yaitu mengenai bagaimana pemanfaatan youtube dalam meningkatkan keterampilan pengelolaan sampah di RW 06 Cibeber. Berdasarkan hasil wawancara dan pengamatan bahwa warga sekitar sangat antusias ketika diberikan pemahaman mengenai tata cara penggunaan youtube, khususnya untuk menonton dan mengaplikasikan konten keterampilan pengelolaan sampah yang dikemas secara baik dan sangat mudah untuk diaplikasikan. Pengelolaan sampah diatur dalam UU No.18 (2008) pada Bab I Pasal I ayat 5 "pengelolaan sampah merupakan kegiatan yang sistematis, menyeluruh dan berkelanjutan yang meliputi pengurangan dan penanganan sampah". Selanjutnya pada Bab II mengenai Pasal 4 yang berbunyi "sampah dijadikan sumber daya dalam pengelolaannya untuk meningkatkan kesehatan masyarakat dan lingkungan". Membuktikan bahwa pengelolaan sampah penting untuk diupayakan dalam pengelolaan sampah khususnya dalam pengelolaan sampah ini dibuat secara terampil melalui media informasi youtube.

Pembahasan yang kedua yaitu bagaimana cara meningkatkan pemahaman kepada masyarakat dalam pemanfaatan sampah melalui youtube. Berdasarkan hasil lapangan peneliti melaksanakan penyuluhan yang mengikutsertakan masyarakat Rw.06 Cibeber mengenai pentingnya mengelola sampah. Youtube adalah situs berupa video yang memberikan 
informasi secara langsung kepada penggunanya dan memiliki jangkauan seluruh dunia (Baskoro \& Adi, 2009). Dalam pelaksanaan kegiatan penyuluhan peneliti menyampaikan informasi kepada masyarakat mengenai penggunaan youtube sebagai alat informasi yang memuat mengenai daur ulang sampah. Dalam kegiatan penyuluhan tersebut, peneliti sekaligus mengajak masyarakat untuk mempraktikkan langsung cara mengolah sampah menjadi barang yang bisa bermanfaat kembali. Menurut (Hayat \& Zayadi, 2018) pengelolaan sampah harus dilakukan untuk mendapatkan lingkungan yang bersih dan sehat, maka dari itu sampah harus dikemas dengan baik.

Pembahasan yang ketiga yaitu bagaimana hambatan-hambatan yang di hadapi dalam meningkatkan keterampilan pengelolaan sampah berdasarkan hasil pengamatan dilapangan peneliti mendapatkan hasil bahwa setelah diadakannya penyuluhan dan pelatihan dalam pengelolaan sampah perlu diadakannya pengecekan secara berkelanjutan agar masyarakat dapat terus mengaplikasikan keterampilan pengelolaan sampah dengan baik. Karena pentingnya pengelolaan sampah yang dikemas menjadi sebuah produk dengan menggunakan tangan yang terampil dapat membuahkan hasil yang diperoleh dalam pemanfaatan sampah. Kreativitas dalam KBBI didefinisikan sebagai 1) kemampuan untuk mencipta; daya cipta; 2) perihal berkreasi; kekratifan, sedangkan menurut kamus Oxford kreativitas didefinisikan sebagai kemampuan untuk mengembangkan ide baru, berusaha memunculkan pemikiranpemikiran baru dan menemukan cara baru untuk melakukan sesuatu. Dengan pemberian pemahaman mengenai penggunaan youtube masyarakat dapat menggunakan youtube sebagai media informasi yang dapat diakses secara mudah juga diharapkan dapat merubah sikap warga masyarakat terhadap pentingnya pengelolaan sampah yang dapat disampaikan melalui penggunaan youtube sebagai media informasi.

\section{KESIMPULAN}

Pemanfaatan youtube sebagai upaya meningkatkan kreativitas masyarakat Rw.06 Cibeber mengenai pengelolaan sampah dapat menghasilkan perubahan salah satunya adalah untuk memberikan pemahaman kepada masyarakat tentang penggunaan media sosial youtube sebagai penyedia informasi dalam upaya meningkatkan keterampilan masyarakat mengenai pengelolaan sampah. Adanya penumpukkan sampah yang terjadi ini menjadi keresahan warga Cibeber dan menyadarkan masyarakat akan pentingnya pengelolaan sampah. selanjutnya dengan memberikan pemahaman kepada masyarakat melalui penggunaan media sosial youtube sebagai upaya meningkatkan keterampilan masyarakat mengenai pengelolaan sampah ini adalah masyarakat dapat lebih paham cara menggunakan youtube sebagai alat informasi khususnya mengenai bagaimana cara pengelolaan sampah menjadi benda yang dapat bermanfaat.

\section{DAFTAR PUSTAKA}

Baskoro \& Adi. (2009). Panduan Praktis Searching di Internet. Jakarta: PT.Trans Media.

Chandra, \& Budiman. (2006). Pengantar Kesehatan Lingkungan. Jakarta: EGC.

Fatty Faiqah. (2016). Youtube Sebagai Sarana Komunikasi Bagi Komunitas Makassar Vidgram. Jurnal Komunikasi KAREBA 5(2), 262-263.

Hayat, \& Zayadi, H. (2018). Model Inovasi Pengelolaan Sampah Rumah Tangga. Jurnal Ketahanan Pangan 2(2), 131-141. 
108 Nurislam, Pemanfaatan Youtube Dalam Upaya Meningkatkan Keterampilan Masyarakat

RW 06 Cibeber Mengenai Pengelolaan Sampah

Dinas Lingkungan Hidup Kota Cimahi. (2019). Jumlah Sampah kota cimahi. Cimahi: DLH Kota Cimahi Tidak Diterbitkan.

Radar Bandung. (2019). Kota Cimahi Hasilkan 300 Ton Sampah Perhari. Cimahi: Radar Bandung.

Kustiah, T. (2005). Kajian Kebijakan Pengelolaan Sanitasi Berbasis Masyarakat, . Bandung: Badan Penelitian dan Pengembangan Departemen Pekerjaan Umum.

Kementerian Keuangan RI(2019). Media Keuangan Transparansi Informasi Kebijakan Fiskal. Jakarta; Kementrian Keuangan RI.

Mursidi, B., Fitriah, \& Aldiawan. (1019). Analisis Transportasi pengangkutan Sampah Kec. kambu Kota Kendari. Stabilita Jurnal Ilmiah Teknik Sipil 7(3), 245-252.

Rizal, M. (2011). Analisis Pengelolaan Persampahan Perkotaan. Jurnal Smartek 9(2), 155172.

Sugiyono. (2011). Metode Penelitian Kuantitatif, Kualitatif dan R\&D. Bandung: ALFABETA.

Widika, T. (2013). Sejarah Berdirinya Youtube. Retrieved from Sejarah Dunia: https://canacantya.wordpress.com/sejarah/sejarah-berdirinya-Youtube

Zubaedi. (2013). Pengembangan Masyarakat. Jakarta: Kencana Prenada Media Group. 